\title{
CAMPUR KODE PEMAKAIAN BAHASA INDONESIA PADA WACANA IKLAN
}

\author{
I Nengah Mileh \\ Universitas Warmadewa \\ milehmenuri@gmail.com
}

\begin{abstract}
ABSTRAK
Penelitian ini berjudul 'Campur Kode Bahasa Indonesia Pada Wacana Iklan'. Pemakaian bahasa Indonesia pada wacana iklan telah terjadi penyisipan unsur-unsur bahasa lain, yaitu bahasa daerah dan bahasa asing. Penelitian ini mengkaji faktor-faktor yang menyebabkan munculnya campur kode, macam dan bentuk/wujud campur kode, serta makna sosial yang ditimbulkan oleh campur kode tersebut. Penelitian menggunakan metode simak (observasi) dan teknik catat dalam pengumpulan data, metode kualitatif yang bersifat deskriptif digunakan dalam menganalisis data, dan metode informal digunakan untuk menyajikan hasil analisis. Dalam penelitian ini ditemukan dua macam campur kode, yaitu campur kode ke dalam dengan bahasa daerah (Bali dan Jawa) dan campur kode ke luar dengan bahasa Inggris. Bentuk dan wujud campur kode yang ditemukan adalah campur kode berwujud kata, yaitu kata benda, kata kerja, kata sifat dan kata keterangan. Selain berwujud kata juga ditemukan campur kode berwujud frase, yaitu frase nominal, frase verbal, dan frase preposisi. Penyebab campur kode pada wacana iklan ada dua, yaitu faktor intralinguistik dan faktor ekstralinguistik. Peristiwa campur kode pada wacana iklan terkait dengan bahasa dan gejala sosial yang melatarinya, sehingga muncul makna sosial akibat prilaku campur kode tersebut. Makna sosial yang muncul, yaitu menunjukkan lebih terpelajar, menunjukkan kelas sosial, menunjukkan daya kreativitas, menunjukkan kepraktisan dan kedaerahan.
\end{abstract}

Kata kunci: bahasa; campur kode; iklan; kontak

\begin{abstract}
This study is entitled "Mixing Indonesian Language Codes in Advertising Discourse". The use of Indonesian in discourse advertisements has taken place in another language, namely local languages and foreign languages. This study examines the factors that cause code mixing, the types and forms / forms of code mixing, and the social meaning that is caused by the code mixing. The study uses the method of observation (observation) and data collection techniques, descriptive qualitative methods used in analyzing data, and informal methods used to collect the results of the analysis. In this study found two kinds of mixed codes, namely mixed codes into local languages (Balinese and Javanese) and mixed codes out of English. The shape and form of the code that is found is a mixture of code in the form of words, namely nouns, verbs, adjectives and adverbs. In addition to the form of words also found a mixture of code in the form of phrases, namely nominal phrases, verbal phrases, and prepositional phrases. There are two causes of code mixing in discourse, namely intralinguistic factors and extralinguistic factors. The code mixing events in the discourse are related to the language and social background, so that social meaning arises due to the code mixing behavior. Social meaning that emerges, shows more educated, shows social class, shows creativity, and shows the practical and regionalism.
\end{abstract}

Keywords: language; contacts; advertisements; code capable

\section{PENDAHULUAN}

Masyarakat Indonesia termasuk masyarakat yang majemuk yang terdiri atas berbagai suku bangsa, agama, adat-istiadat, dan bahasa. Kemajemukan dalam bidang bahasa merupakan salah satu kekayaan budaya yang sangat berharga dan merupakan lahan yang 
cukup baik bagi penelitian kebahasaan dari berbagai seginya.

Kontak bahasa yang terjadi dalam masyarakat majemuk akan menimbulkan peristiwa-peristiwa kebahasaan sebagai akibatnya. Peristiwa-peristiwa kebahasaan yang ditimbulkan, dalam sosiolinguistik dapat berupa kedwibahasaan, alih kode, pergeseran bahasa, campur kode (CK), dan sebagainya (Chaer \& Agustina, 1995)

Di dalam masyarakat yang beraneka bahasa, seperti Indonesia, sikap bahasa merupakan salah satu masalah yang perlu mendapat perhatian. Masyarakat Indonesia, pada umumnya di samping menguasai bahasa daerahnya, juga menguasai bahasa Indonesia sebagai sarana komunikasi. Bahkan, pada kenyataannya tidak sedikit pula orang Indonesia yang menguasai bahasa asing (Inggris).

Penyusun teks wacana iklan niaga bahasa Indonesia adalah juga penutur bahasa yang dwibahasawan atau anekabahasawan, karena pada umumnya bagi masyarakat Indonesia, bahasa Indonesia menjadi bahasa kedua. Para penyusun iklan niaga bahasa Indonesia yang juga dwibahasawan atau anekabahasawan itu, diasumsikan menguasai bahasa asing (Inggris), dalam hal ini, sudah tentu dengan derajat penguasaan yang beragam. Dengan situasi kebahasaan yang demikian, tidak tertutup kemungkinan dalam iklan niaga media massa cetak dan elektronik akan terjadi peristiwa bahasa seperti campur kode, alih kode, dan sebagainya, seperti yang lazim ditemukan di dalam masyarakat bahasa yang lain (Nababan, 1993; Weinreich, 1974)

Secara umum, sebuah wacana iklan dibangun oleh beberapa unsur. Bahasa merupakan salah satu unsur di antara beberapa unsur yang membangun wacana iklan . Bagian iklan yang dapat diteliti secara linguistis hanyalah unsur teksnya (Utorodewo, 1998).

Bahasa yang digunakan dalam iklan pun mengalami perkembangan yang cukup pesat. Bahasa dalam iklan dewasa ini cenderung lebih kaya jika dibandingkan dengan iklan tahun-tahun sebelumnya. Penggunaan bahasa campuran baik yang diambil dan bahasa daerah maupun bahasa asing (Inggris) semakin semarak.
Berdasarkan uraian di atas, dapat diasumsikan bahwa teks wacana iklan niaga bahasa Indonesia bercampur dengan unsur bahasa lain (bahasa daerah atau bahasa asing), khususnya pada media massa cetak. Teks wacana iklan tersebut disusun pengiklan ditujukan kepada kelompok sosial tertentu dalam masyarakat yang diprakirakan dapat menjadi sasaran barang atau jasa niaga. Variasi unsur-unsur bahasa yang berbeda pada wacana iklan komersial menunjukkan adanya peristiwa bahasa yang disebut campur kode. Hal inilah yang mendasari peneliti tertarik untuk meneliti campur kode pada wacana iklan.

Berdasarkan paparan pada latar belakang di atas, dapat dibuat rumusan masalah sebagai berikut.

1) Bagaimanakah macam dan wujud campur kode pada wacana iklan?

2) Faktor-faktor apa yang menyebabkan terjadinya campur kode pada wacana iklan?

3) Makna sosial apakah yang ditimbulkan sebagai akibat adanya campur kode pada wacana iklan?

\section{METODE}

Dalam mengumpulkan data untuk penelitian ini digunakan metode simak dengan teknik catat (Sudaryanto, 2015). Metode simak digunakan dalam melakukan observasi terkait iklan-iklan yang menggunakan campur kode dalam penyajiannya dan teknik catat digunakan untuk merekap data-data terpilih yang akan dianalisis. Mendukung metode tersebut, metode kualitatif yang bersifat deskriptif digunakan dalam menganalisis data, dan metode informal digunakan untuk menyajikan hasil analisis data dengan kata-kata, baik secara harfiah maupun terminologis (Sudaryanto, 2015).

\section{PEMBAHASAN Pengertian Campur Kode}

Campur kode dapat terjadi apabila seseorang ketika berbicara mencampur dua bahasa atau lebih dalam suatu tindak bahasa tanpa ada sesuatu dalam sitruasi berbahasa itu yang menuntut percampuran bahasa tersebut Dalam keadaan yang demikian, hanya kesantaian dan kebiasaan penutur ketika 
berbicara sehingga tindak bahasa semacam itu disebut campur kode (Nababan, 1993:32).

Menurut (Gumperz, 1982), campur kode merupakan serpihan-serpihan bahasa lain yang digunakan oleh seorang penutur dalam pembicaraan yang sifatnya kesantaian. Serpihan-serpihan bahasa yang diambil dari bahasa lain tanpa mendukung fungsi bahasa, melainkan fungsinya telah menyatu terhadap serpihan bahasa yang disisipinya. Serpihanserpihan bahasa lain yang diambil dan digunakan selain berupa kata dapat pula berupa frase.

Berdasarkan konsep-konsep campur kode yang dikernukakan di atas, penulis cenderung mengacu pada konsep campur kode yang dikemukakan oleh Nababan dan Gumperz, Dari kedua konsep itu, jelas bahwa campur kode dapat terjadi apabila seseorang ketika berbicara mencampur dua bahasa atau lebih dalam situasi tidak resmi ataupun resmi. Akan tetapi, secara umum campur kode sering terjadi dalam situasi tidak resmi.

\section{Jenis Campur Kode}

Berdasarkan unsur-unsur bahasa yang menyisip ke dalam bahasa sasaran, dapat diketahui macam-macam campur kode. Berikut ini disajikan sejumlah wacana iklan komersial yang memuat campur kode.

Wacana 1

Dengan Energal plus, $\boldsymbol{O}$ n terus!

Energal plus, minuman prima di usia prima.

Wacana 2

$\boldsymbol{N E}$ BALI, Air Minumnya Bali.

Pelayanan pelanggan

PT JASA UTAMA

Wacana 3

Mata merah karena iritasi ringan, jangan dipandang sebelah mata!

Kok dikucek?

Wacana 4

Clear anti ketombe.

Ketombe, siapa takut?

Ketombe kabur, rambut keren.

Wacana 5

OTRIVIN Obat Tetes Hidung.

Meringankan hidung tersumbat karena pilek.

Dengan dua tetes otrivin, hidung mampetpun menjadi longgar.

Wacana 6

NOKIA Connecting People.
Bergegaslah dapatkan nokia 5110 garansi resmi \& kartu pra bayar simpati atau pro XL dengan harga pantastis.

Hubungi segera customer service kami!

Wacana 7

Lemari es sharp super big capacity.

Semua bisa masuk, termasuk saya.

1. Campur Kode ke Dalam

Berdasarkan data pada wacana 2, 3, 4, dan 5 di depan, ditemukan unsur-unsur bahasa daerah (bahasa yang sekerabat) yang menyisip ke dalam bahasa sasaran (bahasa Indonesia) pada wacana iklan komersial. Kata bahasa daerah yang menyisip ke dalam bahasa Indonesia ditandai dengan cetakan miring.

Contoh unsur bahasa daerah yang menyisip ke dalam bahasa Indonesia pada wacana iklan, yaitu bahasa Bali ne ini (wacana 2) dan kucek "mengosok-gosok dengan tangan" (wacana 3) dan bahasa Jawa, yaitu kata keren 'baik dan membanggakan' (wacana 4) dan mampet 'buntu' (wacana 5).

Berdasarkan uraian di atas, campur kode tersebut termasuk campur kode ke dalam (inner code-mixing), karena kedua bahasa daerah tersebut memiliki wilayah geografis dan genetis yang sama dengan bahasa Indonesia.

2. Campur Kode ke Luar

Pada wacana 1, 6, dan 7 di depan ditemukan adanya penyisipan unsur bahasa Inggris ke bahasa Indonesia pada wacana iklan, yang berupa kata dan frase. Unsur bahasa Inggris yang menyisip ke dalam bahasa Indonesia pada wacana iklan, yaitu kata on (wacana 1), connecting people, customer service (wacana 6), dan super big capacity (wacana 7). Keempat unsur bahasa Inggris itu memiliki padanan dalam bahasa Indonesia sebagai berikut 'semangat', 'menghubungkan orang', 'pelayan pelanggan', dan 'daya muat yang amat besar'.

Berdasarkan uraian di depan dapat dikatakan bahwa pada wacana 1, 6, dan 7 terjadi Campur kode ke luar, sebab bahasa Inggris dan bahasa Indonesia sama sekali tidak memiliki hubungan yang sama baik secara geografis maupun secara genetis kebahasaan. 


\section{Bentuk Campur Kode}

Untuk mengetahui bentuk-bentuk campur kode pada wacana iklan dapat ditinjau berdasarkan unsur-unsur bahasa yang menyisip ke dalam bahasa sasaran. Jika sebuah wacana dipilah-pilah berdasarkan satuan yang lebih kecil, maka akan ditemukan bentuk-bentuk campur kode yang terjadi pada wacana iklan tersebut.

1. Campur Kode Kata

Berdasarkan data yang tersedia ditemukan adanya campur kode yang berwujud kata, yaitu kata yang berjenis kata benda, kata kerja, kata sifat, dan kata keterangan. Untuk lebih jelasnya berikut ini akan diuraikan secara rinci bentuk-bentuk campur kode kata berdasarkan jenisnya.

a. Campur Kode Kata Benda

Jika diamati secara cermat bentuk campur kode yang berwujud kata pada wacana iklan, ternyata ditemukan campur kode yang berjenis kata benda. Untuk lebih jelasnya dapat diperhatikan pada wacana berikut ini.

Wacana 8

Tahap dua pasti sangat murah!

Diskon 50\% produk fashion.

Wacana 9

Mesin penghitung uang portable.

Wacana 10

Apakah ketidakbebasan bergerak adalah handicap Anda saat bermain golf?

Wacana 11

Spring Bed MARCOPOLO, megah spring bed, quality lebih unggul.

Jika diamati secara cermat pada wacana $8,9,10$, dan 11 di depan, ditemukan jenis kata yang bercampur kode ke dalam bahasa Indonesia, yaitu kite fashion, portable, handicap dan kata quality, keempat kata tersebut berasal dan bahasa Inggris yang berjenis kata benda.

b. Campur Kode Kata Kerja

Selain bentuk campur kode kata benda yang dijumpai pada wacana iklan komersial, juga ditemukan bentuk campur kode berupa kata kerja (verba). Berikut ini wacana yang memuat campur kode kata kerja.
Wacana 12

Gunakan selalu SLI 501

Raih liburan gratis ke mancanegara Call \& fly 001

Wacana 13

Sale s/d 70\%, 1 Agustus - 31 Agustus 1999.

Selama persediaan masih ada.

Wacana 14

Istana arloji jual \& service, segala jenis merek dan arloji.

Jika diperhatikan bentuk-bentuk campur kode kata yang tertera pada wacana iklan komersial 12, 13, dan 14 di depan, ditemukan unsur kata kerja yang bercampur pada wacana tersebut Kata-kata yang bercampur kode, yaitu kata call, fly, sale, dan service.

c. Campur Kode Kata Sifat

Dalam penelitian ini juga ditemukan campur kode yang berwujud kata sifat. Untuk lebih jelasnya berikut ini disajikan kutipan wacana yang memuat campur kode yang berwujud kata sifat.

Wacana 15

Temukan keserasian dan perpaduan warna idaman pada Yamaha Crypton new model 99.

Wacana 16

Saat tubuh anda butuh multivitamin minum Supertin.

Dalam menjalani hari-hari saya, kesehatan itu amat berharga. Untuk

Membantu menjaga kesehatan saat tubuh butuh multivitamin, saya minum Supertin, multivitamin dan mineral lengkap dalam soft kapsul.

Wacana 17

Yamaha hadiah langsung jaket kulit exclusive untuk pembelian RX King cash atau kredit.

d. Campur Kode Kata Keterangan

Selain campur kode berwujud kata benda, kata kerja dan kata sifat juga ditemukan campur kode yang berwujud kata keterangan. Untuk lebih jelasnya mengenai bentuk campur kode yang berwujud kata keterangan datum wacana - iklan, berikut ini disajikan sejumlah wacana iklan yang memuat campur kode tersebut. 
Wacana 18

YAMAHA

Hadiah langsung jaket kulit exclusive

Untuk pembelian RX-KING $\boldsymbol{c}$ ash atau

kredit.

Wacana 19

LASER PRINTER HL - 1040

TERCEPAT DI KELASNYA

NEW.

Wacana 20

Always coca cola, reguk kesegarannya.

Bila diperhatikan pada wacana 18 ,

19, dan wacana 20 di depan ditemukan adanya campur kode yang berwujud kata. Campur kode kata yang terjadi pada wacana iklan komersial tersebut jika ditinjau dari sudut jenis katanya ternyata termasuk ke dalam jenis kata keterangan. Kata yang dimaksud adalah kata cash pada wacana I8, kata new pada wacana 19 , dan kata always pada wacana 20.

Berdasar analisis data dapat disimpulkan bahwa campur kode yang berwujud kata benda lebih dominan jika dibandingkan dengan campur kode yang lainnya, Menurut asumsi peneliti hal ini wajar terjadi karena dalam wacana iklan komersial yang banyak diiklankan adalah barang atau benda yang berkaitan dengan kebutuhan hidup manusia. Namun, untuk membuktikan kebenaran asumsi ini diperlukan penelitian lebih lanjut.

2. Campur Kode Berwujud Frase

Pada data wacana iklan komersial juga ditemukan adanya campur kode yang berwujud frase. Untuk lebih jelasnya di bawah ini akan dipaparkan secara rinci bentuk-bentuk campur kode yang berwujud frase.

Kalau diperhatikan secara saksama pada wacana 15, 16, dan 17 di depan, ditemukan campur kode yang berwujud kata. Kata yang bercampur kode pada wacana tersebut di atas dapat dikelompokkan ke dalam kata yang berjenis kata sifat Kata yang dimaksud adalah kata new, soft, dan kata exclusive.

Bila diperhatikan pada wacana 18,19 , dan wacana 20 di depan ditemukan adanya campur kode yang berwujud kata. Campur kode kata yang terjadi pada wacana iklan komersial tersebut jika ditinjau dari sudut jenis katanya ternyata termasuk ke dalam jenis kata keterangan. Kata yang dimaksud adalah kata cash pada wacana I8, kata new pada wacana 19, dan kata always pada wacana 20.

Berdasar analisis data dapat disimpulkan bahwa campur kode yang berwujud kata benda lebih dominan jika dibandingkan dengan campur kode yang lainnya, Menurut asumsi peneliti hal ini wajar terjadi karena dalam wacana iklan komersial yang banyak diiklankan adalah barang atau benda yang berkaitan dengan kebutuhan hidup manusia. Namun, untuk membuktikan kebenaran asumsi ini diperlukan penelitian lebih lanjut.

a. Campur Kode yang Berwujud Frase Nominal

Jika diperhatikan pada data yang tersedia ternyata ditemukan adanya campur kode bahasa Inggris yang berwujud frase nominal pada wacana iklan komersial Sebagai bahan kajian pada subbab ini berikut ini disajikan sejumlah wacana yang memuat campur kode frase nominal (benda).

Wacana 21

Nuansa kenyamanan baru

Mitsubisi kuda diesel $2500 \mathrm{cc}$, paling halus getarannya. Test drive di show room kami.

Wacana 22

Kapan dan dimana saja Anda inginkan, Kami antarkan ketentraman.

Dengan fasilitas Room Service kami membuka rekening menjadi begitu mudah.

Wacana 23

Tahukah Anda untuk mesin speed boat perlu minyak lumas khusus? Mesrania 2T Super $-X$. membuat mesin awet muda.

Jika diperhatikan secara saksama pada wacana $6,7,21,22$, dan 23 di depan, maka ditemukan adanya campur kode bahasa Inggris yang berwujud frase nominal ke dalam bahasa Indonesia pada wacana iklan komersial. Frase nominal (benda) tersebut, yakni customer service, super 
big capacity, show room, room service, dan speed boat.

b. Campur Kode yang Berwujud Frase Verbal

Pada data penelitian ini juga ditemukan adanya campur kode yang berwujud frase verbal (kerja). Sebagai bahan kajian berikut ini disajikan wacana iklan komersial yang memuat campur kode yang berwujud frase verbal.

Wacana 24

Memanfaatkan sumber daya alam

pilihan paling tepat bagi kesehatan.

\section{Back to nature}

Daun teratai natural medicine industry Bandung -Indonesia

Bila diperhatikan pada wacana 6 dan wacana 24 di depan ditemukan adanya campur kode yang berwujud frase verbal ke dalam bahasa Indonesia. Frase verbal tersebut, yaitu connecting people dan back to nature.

c. Campur Kode yang Berwujud Frase Preposisi

Dalam data penelitian ini juga dijumpai adanya unsur bahasa Inggris yang bercampur ke dalam bahasa Indonesia dalam wujud frase preposisi. Untuk lebih jelasnya mengenai keberadaan campur kode yang berwujud frase preposisi pada wacana iklan, di bawah ini disajikan sejumlah wacana iklan komersial.

Wacana 25

Sehubungan permintaan pelanggan \& menyambut Galungan \& Kuningan

On sale-week. Diperpanjang $1-6$ Juni 99. Diskon $20-35 \%$ untuk produk three M.

Wacana 26

Beli DISPENSER?

Nikmati KULKASnya, type Alaska by NI PONT. Inovasi baru.

Jika diperhatikan secara saksama pada wacana 25 dan 26 di depan, ditemukan adanya frase preposisi bahasa Inggris bercampur kode ke dalam bahasa Indonesia pada wacana iklan komersial.
Berdasarkan analisis data ternyata campur kode yang berwujud frase nominal lebih dominan jika dibandingkan dengan campur kode yang wujud frase lainnya. Hal ini wajar sebab yang lebih banyak diiklankan dalam wacana iklan komersial adalah benda-benda atau barang-barang yang berkaitan dengan kebutuhan manusia. Untuk membuktikan kebenaran asumsi ini diperlukan penelitian lebih lanjut.

\section{Faktor Penyebab dan Makna Campur Kode}

1. Faktor Penyebab Terjadinya Campur Kode Berdasarkan analisis data pada wacana iklan komersial dapat ditemukan dua faktor yang menyebabkan terjadi campur kode. Faktor yang pertama adalah faktor intralinguistik dan kedua faktor ekstralinguistik.

2. Faktor Intralinguistik

Faktor intralinguistik maksudnya bahwa faktor-faktor yang menyebabkan timbulnya campur kode pada wacana iklan komersial disebabkan oleh faktor bahasa itu sendiri. Dengan kata lain, bahasa sebagai sistem kode dapat menyebabkan terjadinya campur kode pada wacana iklan komersial.

Jika diperhatikan dan segi intralinguistik, penyisipan unsur-unsur bahasa Inggris ke dalam bahasa Indonesia pada wacana iklan komersial, disebabkan oleh dua faktor, yaitu (a) keluasan makna dan (b) ketepatan rasa (makna).

a. Keluasan makna

Iklan merupakan hasil manipulasi bahasa untuk mencapai tujuan tertentu (Utorodewo, 1998). Iklan merupakan usaha persuasi. Makin terbatas jumlah kosa kata yang digunakan dalam sebuah wacana makin tinggi kepentingan penggunaan unsur bahasa yang hemat dan cermat.

Penggunaan bentuk bahasa yang lebih sederhana tetapi memiliki makna yang lebih luas juga merupakan kecenderungan para pemakai bahasa: lebih-lebih para pengiklan yang mementingkan pemakaian bentuk bahasa yang lebih simpel, padat, dan praktis serta tidak menyimpang dari 
kaidah dan makna bahasa yang digunakan. Contoh kata yang menunjukkan keluasan makna antara lain kata on (pada wacana 1) dan kata soft (wacana 16), jika dibandingkan dengan padanannya dalam bahasa Indonesia.

b. Ketepatan Rasa (Makna)

Kemampuan berbahasa yang mesti dimiliki oleh pengiklan antara lain, pertama kemampuan pemilihan kata yang tepat dan sesuai, yang hanya dimungkinkan oleh penguasaan sejumlah kosa kata suatu bahasa; kedua, kemampuan membedakan secara tepat nuansa-nuansa makna yang sesuai dengan gagasan yang ingin disampaikan dan kemampuan untuk menemukan bentuk yang sesuai dengan situasi dan nilai rasa yang dimiliki oleh kelompok masyarakat tertentu (Sudewo, 1995:2).

Penyisipan unsur bahasa Inggris ke dalam bahasa Indonesia pada wacana iklan komersial oleh pengiklan, tentu dilandasi suatu pemikiran agar makna atau nilai rasa yang dimunculkan oleh campur kode tersebut mampu mempersuasi pembacanya. Oleh karena itu, ketepatan dan kesesuaian pilihan kata atau frase oleh pengiklan sangat menentukan nuansa makna yang ditimbulkan.

Campur kode kata fashion (wacana S) dan kata exclusive (wacana 17) dipandang memiliki nuansa makna yang lebih tepat jika dibandingkan dengan padanannya dalam BI.

3. Faktor Ekstralinguistik

Faktor ekstralinguistik maksudnya faktorfaktor di luar bahasa yang menyebabkan terjadinya campur kode pada wacana iklan komersial. Faktor-faktor tersebut, yaitu (1) tujuan pengiklan, (2) pendidikan pengiklan, dan (3) pengaruh globalisasi.

a. Tujuan Pengiklan

Penyusun teks wacana iklan komersial yang menyisipkan unsurunsur bahasa Inggris pada wacana iklan, bertujuan untuk mencapai sasaran pada masyarakat calon konsumen dari kelas sosial ekonomi tertentu. Kelas sosial ekonomi yang dimaksud di sini adalah kelas ekonomi menengah ke atas,

Penggunaan unsur bahasa Inggris pada wacana iklan komersial seperti kata fashion (wacana 8), portable (wacana 9), exclusive (wacana 17) dan sebagainya, serta frase test drive, show room (wacana 21), room service (wacana 22), dan sebagainya, merupakan hal yang sudah lazim didengar atau diucapkan oleh kelompok masyarakat dari kelas ekonomi menengah ke atas. Jadi, jelas tujuan pengiklan menyisipkan unsurunsur bahasa Inggris pada wacana iklan komersial adalah untuk mencapai sasaran pada .kelompok masyarakat tertentu.

b. Pendidikan Pengiklan

Mengingat pemilihan unsur-unsur bahasa yang digunakan pada wacana iklan komersial begitu rumit, maka diperlukan kemampuan dan keterampilan yang baik untuk merekayasa bahasa sehingga dapat menimbulkan daya tank bagi pembacanya.

Kemampuan dan keterampilan mengolah bahasa iklan sudah tentu memerlukan pelatihan dan pendidikan yang cukup untuk itu. Semakin tinggi pendidikan dan pengalaman penyusun teks wacana iklan semakin tinggi pula kemampuan dan keterampilannya menguasai dan menggunakan bahasa dalam iklan.

Demikian pula halnya dengan pengiklan dalam menyisipkan unsurunsur bahasa asing (Inggris) maupun bahasa daerah ke dalam bahasa Indonesia pada wacana iklan komersial sangat dipengaruhi oleh pendidikan si penyusun teks wacana iklan yang bersangkutan. Jadi dengan kata lain dapat diasumsikan bahwa semakin tinggi pendidikan seseorang akan semakin besar peluangnya untuk melakukan campur kode, hal ini terjadi bila ia memiliki loyalitas terhadap bahasanya biasa-biasa saja.

c. Pengaruh Globalisasi 
Bahasa asing yang dominan dipakai oleh sebagian masyarakat Indonesia adalah bahasa Inggris. Sebagaimana diketahui bahasa Inggris adalah salah satu bahasa dunia.

Demikian pula dengan pengiklan dalam menyusun teks wacana iklan tidak bisa lepas dari pengaruh globalisasi tersebut Globalisasi memberi peluang dan mendorong pen gild 211 untuk menyisipkan unsurunsur bahasa asing terutama bahasa Inggris ke dalam bahasa Indonesia pada wacana iklan komersial, dengan harapan dapat memberikan informasi tentang suatu produk atau barang secara lebih luas.

\section{Makna Campur Kode}

Untuk dapat mengkaji makna yang muncul akibat campur kode pada wacana iklan diperlukan a daily a kajian dari tiga ciri konteks situasi, yaitu medan (field)., pelibat (tenor), dan sarana (mode), Medan (field] wacana maksudnya menunjuk pada hal yang sedang terjadi; apa sesungguhnya yang sedang disibukkan oleh para pelibat, pelibat (tenor) maksudnya menunjuk pada orang-orang yang mengambil bagian dalam suatu peristiwa, dan yang dimaksud dengan sarana (mode) adalah menunjuk pada bagian yang diperankan oleh bahasa (Halliday \& R, 1980).

Berdasarkan data penelitian yang ada ditemukan adanya beberapa makna yang muncul akibat campur kode pada wacana iklan komersial. Adapun makna yang muncul, yaitu (1) menunjukkan lebih terpelajar, (2) menunjukkan kelas sosial, (3)menunjukkan kepraktisan, dan (4) menunjukkan kedaerahan.

1. Menunjukkan Lebih Terpelajar

Penyisipan unsur-unsur bahasa Inggris oleh penyusun teks wacana iklan menunjukkan orang tersebut memiliki pendidikan yang cukup tinggi, mempunyai pandangan yang luas serta menunjukkan orang masa kini (Suwito, 1983).

Unsur-unsur bahasa Inggris yang bercampur kode ke dalam bahasa Indonesia dapat dilihat pada beberapa wacana antara lain, wacana 1, 6, 7, dan sebagainya. Pada wacana 1 ditemukan preposisi on, pada wacana 6 ditemukan penggunaan frase customer service, dan pada wacana 7 ditemukan frase super big capacity.

Dalam bal ini dapat dikatakan bahwa penyisipan unsur-unsur bahasa Inggris ke dalam bahasa Indonesia oleh pengiklan dengan maksud untuk menimbulkan makna sosial tertentu bagi pembacanya. Sebagaimana diketahui bahasa Inggris sebagai salah satu bahasa dunia yang biasanya dikuasai oleh kaum terpelajar atau terdidik, maka penggunaan unsur-unsur bahasa Inggris pada wacana iklan komersial dapat dianggap menunjukkan makna lebih terpelajar.

2. Menunjukkan Kelas Sosial

Mengingat fungsi bahasa dalam sebuah wacana iklan komersial sangat penting untuk dapat mempersuasif konsumennya, maka pengiklan memerlukan kecermatan dalam memilih unsur-unsur bahasa yang akan digunakan dalam wacana iklan komersial. Pencampurkodean unsur-unsur bahasa Inggris ke dalam bahasa Indonesia pada wacana iklan komersial dengan maksud untuk mencapai sasaran pada kelompok tertentu dalam masyarakat.

Sebagaimana diketahui dalam masyarakat kita dijumpai adanya pembedaan kelas sosial ditinjau dari segi ekonomi, yaitu kelas ekonomi menengah ke atas dan kelas ekonomi menengah ke bawah. Dengan demikian, dapat dikatakan bahwa penyisipan unsur-unsur bahasa Inggris oleh pengiklan dimaksudkan untuk menunjukkan bahwa iklan komersial itu ditujukan kepada kelas sosial ekonomi menengah ke atas.

3. Menunjukkan Kepraktisan

Penguasaan diksi yang baik akan membantu pengiklan dalam menciptakan ungkapan-ungkapan yang persuasif, Pilihan kata yang tepat dan sesuai akan menimbulkan makna yang sesuai dengan harapan yang ingin dicapai oleh pengiklan.

Sebagai wujud ketepatan dan kesesuaian dalam pemilihan unsur-unsur bahasa dalam wacana iklan adalah dengan memperhatikan kepraktisan dan kehematan unsur bahasa tersebut. Sebagai contoh dapat diperhatikan pada preposisi on pada wacana 1 , kata fashion pada wacana 8 , show room pada wacana 17 , dan 
sebagainya. Ketiga unsur bahasa Inggris tersebut dipandang lebih praktis digunakan dalam iklan jika dibandingkan dengan menggunakan unsur bahasa yang menjadi padanannya dalam bahasa Indonesia.

4. Menunjukkan Kedaerahan

Penyisipan unsur bahasa daerah ke dalam bahasa Indonesia pada wacana iklan komersial dimaksudkan untuk menimbulkan makna tertentu bagi pembacanya. Campur kode dengan bahasa daerah tertentu menunjukkan bahwa pengiklan ingin menonjolkan kekhasan, keunikan, ketenaran, ataupun menunjukkan jumlah penutur yang banyak.

Untuk lebih jelasnya di bawah ini disebutkan sejumlah wacana yang memuat campur kode bahasa daerah yang menyisip ke dalam bahasa Indonesia. Kata bahasa Bali ne (wacana 2) digunakan oleh pengiklan dimaksudkan untuk menimbulkan makna tertentu, karena nama Bali sudah sangat terkenal maka makna yang muncul adalah makna kedaerahan. Pada hal kata ne memiliki padanan dengan kata "ini" dalam bahasa Indonesia. Di samping adanya penyisipan unsur bahasa Bali, juga ditemukan penyisipan unsur bahasa Jawa. Unsur bahasa Jawa yang menyisip, yaitu dikucek (wacana 3) dan keren (wacana 4), kedua kata itu dipilih karena jumlah penutur bahasa Jawa cukup besar, sehingga dengan demikian diharapkan barang yang diiklankan akan terjual lebih banyak.

\section{SIMPULAN}

Berdasarkan uraian dan paparan di depan dapat disimpulkan sebagai berikut. Pertama, berdasarkan analisis data ditemukan adanya campur kode ke dalam, yaitu dengan bahasa daerah dan campur kode keluar dengan bahasa Inggris.

Kedua, berdasarkan bentuk dan wujudnya dalam wacana iklan ditemukan campur kode yang berwujud kata, yaitu kata benda, kata kerja, kata sifat, dan kata keterangan. Selain campu kode berwujud kata juga ditemukan campur kode berwujud frase, yaitu frase nominal, frase verbal, dan frase preposisi.

Ketiga, Penyebab munculnya campur kode pada wacana iklan disebabkan oleh dua factor, yaitu faktor Intralinguistik dan faktor ekstralinguistik. Faktor intralinguistik maksudnya factor dalam bahasa itu sendiri, faktor ini meliputi keluasan makna dan ketepatan makna (rasa). Faktor ekstralinguistik maksudnya faktor di luar bahasa itu sendiri, meliputi tujuan pengiklan, pendidikan pengiklan, kreativitas pengiklan, dan pengaruh globalisasi.

Kempat, Peristiwa campur kode pada wacana iklan tersebut dapat memunculkan suatu makna tertentu. Hal ini disebabkan oleh adanya persentuhan fenomena bahasa dengan fenomena sosial. Makna yang timbul akibat campur kode pada wacana iklan antara lain, menunjukkan lebih terperlajar, menunjukkan kelas sosial, menunjukkan daya kreativitas, menunjukkan kepraktisan dan menunjukkan kedaerahan.

\section{DAFTAR PUSTAKA}

Chaer, A. dan, \& Agustina, L. (1995). Sosiolinguistik Perkenalan Awal. Rineka Cipta.

Gumperz. (1982). Discourse Strategies. Cambridge University Press.

Halliday, M. A. K. dan, \& R, H. (1980). Language, Context, and text Aspect of language in Social Semiotic Perspective. All Right.

Nababan, P. W. . (1993). Sosiolinguistik Suatu Pengantar. Gramedia Pustaka. Utama.

Sudaryanto. (2015). Metode dan Aneka Teknik Analisis Bahasa. Sanata Dharma University Press.

Suwito. (1983). Sosiolinguistik Teori dan Problema. Kanary Offset.

Utorodewo, F. (1998). Iklan Sebagai Media Pembinaan Bahasa Indonesia. Departemen Pendidikan dan Kebudayaan Republik Indonesia.

Weinreich, U. (1974). Languages in Contact: Findings and Problems. Mouton. 